\title{
GEOLOGIC FEASIBILITY OF \\ SELECTED CHALK-BEARING SEQUENCES \\ WITHIN THE CONTERMINOUS UNITED STATES \\ WITH REGARD TO SITING OF RADIOACTIVE- \\ WASTE REPOSITORIES
}

Dr. Serge Gonzales

Department of Geology

University of Georgia

Athens, Georgia 30602

November, 1975

MASTER

This report was prepared by Serge Gonzales under Consultant Subcontract 4310 with Union Carbide Corporation, Nuclear Division. The subcontract was administered by Oak Ridge Nationa) Laboratory

This informal document contains information which is preliminary and may be fragmentary or of 1 imited scope. The assumptions, views, and conclusions expressed in this document are those of the author and are not to be interpreted as those of Union Carbide Corporation, Nuclear Division, or USERDA 


\section{DISCLAIMER}

This report was prepared as an account of work sponsored by an agency of the United States Government. Neither the United States Government nor any agency Thereof, nor any of their employees, makes any warranty, express or implied, or assumes any legal liability or responsibility for the accuracy, completeness, or usefulness of any information, apparatus, product, or process disclosed, or represents that its use would not infringe privately owned rights. Reference herein to any specific commercial product, process, or service by trade name, trademark, manufacturer, or otherwise does not necessarily constitute or imply its endorsement, recommendation, or favoring by the United States Government or any agency thereof. The views and opinions of authors expressed herein do not necessarily state or reflect those of the United States Government or any agency thereof. 


\section{DISCLAIMER}

Portions of this document may be illegible in electronic image products. Images are produced from the best available original document. 
This report was prepared as an account of work sponsored by the United States Government. Neither the United States nor the Energy Research and Development Administration, nor any of their employees, nor any of their contractors, subcontractors, or their employees, makes any warranty, express or implied, or assumes any legal liability or responsibility for the accuracy, completeness or usefulness of any information, apparatus, product or process disclosed, or represents that its use would not infringe privately owned rights. 
FINAL REPORT

GEOLOGIC FEASIBILITY OF

SELECTED CHALK-BEARING SEQUENCES

WITHIN THE CONTERMINOUS UNITED STATES

WITH REGARD TO SITING OF RADIOACTIVE-

WASTE REPOSITORIES

Submitted to

Union Carbide Corporation

Oak Ridge National Laboratories

Oak Ridge, Tennessee 37830

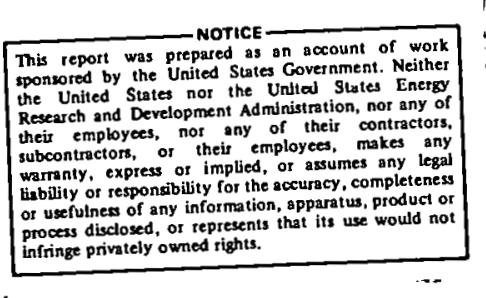

Under

Subcontract 4310

W-7405-ENG 26

Prepared by

Dr. Serge Gonzales

Department of Geology

University of Georqia

Athens:, Georgia 30602

November, 1975 


\section{TABLE OF CONTENTS}

Topic/Item

$\underline{\text { Page }}$

INTRODUCTION

PHYSIOGRAPHIC SETTING

SEISMICITY, TECTONICS, AND GEOLOGIC STRUCTURE

STRATIGRAPHY AND LITHOLOGY

HYDROLOGY

Surface. Water

Ground Water

MINERAL RESOURCES

PHYSICAL-CHEMICAL PROPERTIES

GENERAL EVALUATION OF CHALK-BEARING SEQUENCES FOR WASTE REPOSITORY 


\section{Figures}

1

2

3

4

5.

6

7

\section{Tables}

Idealized geologic time-rock classification of chalk-bearing stratigraphic intervals in the United States

Location of the Upper Cretaceous Niobrara Formation, Austin Chalk and Selma Group and some minor chalks within the physiographic provinces containing these units

Physiographic setting and topographic belts developed in the East and West Gulf Coastal Plain relative to the outcrop patterns of the Austin Chalk and Selma Group

Physiographic setting of the Niobrara Formation within the Great Plains showing westward dissection along east-flowing streams and relationship of west-dipping strata and consequent, east-sloping land surface

Seismic-risk map of the conterminous United states with the outcrop belts of Niobrara Formation, Austin Chalk, Selma Group and some minor chalks

Semi-regional plots of epicentral locations for seismic events above Intensity $\mathrm{V}$ in states containing principal chalk-bearing sequences

Generalized stratigraphic relations of the Selma Group formations from eastern

Alabama to southern Tennessee

Active Limestone Quaries Within The Austin, Niobrara and Selma Chalks 


\subsection{Chalk-Bearing Rocks}

\section{INTRODUCTION}

This report evaluates various geologic and hydrologic parameters in relation to assessing the potential for repository storage of high-level radioactive wastes within several stratigraphic sequences dominated by chalks and chalky limestones. The former lithology is defined as a carbonate rock consisting mainly of very fine-grained particles of micritic calcite. Although chalks also contain coarser-grained particles such as shells of fossil foraminifera and non-calcitic minerals like quartz, most contain more than 90 percent micritic material. The latter represents broken fossil coccolith plates. Chalks generally are soft, friable rocks of low density, and appear almost cxyptogranular. Harvey and others (1974) have determined that the mean grain size of several well-known chalks was only from 2.1 to 3.0 micromillimeters $(\mu \mathrm{m})$ in diameter. The abundant micritic matrix in these same chalks averaged only 1.5 micromillimeters (um) in diameter. Chalky limestones, although also mainly micritic in composition, differ from true chalks in being less friable, harder and more competent, although decidedly less so than Paleozoic-age micritic Iimestones (Frey, 1972).

Regionally extensive chalk-bearing intervals on a worldwide basis are primarily Cretaceous in age. Within the United states, the more prominent chalk-bearing formations are more specifically found within the Upper Cretaceous, although some chalks and chalky limestones occur within Tertiary-age stratigraphic sequences. The: best known Upper Cretaceous "chalks" are 
the Niobrara Formation of central Kansas, eastern Nebraska and eastern Colorado; the nustin Chalk of east-central Texas; and the Mooreville, Demopolis and Prairie Bluff Formations within the Selma Group of south-central Alabama and eastern Mississippi. Other less significant Upper Cretaceous-age chalk units include portions of the Greenhorn Iimestone of western Kansas; the Pecan Gap Chalk of northeast Texas; the Annona Chalk of northwest Texas and southwest Arkansas; and the Saratoga Chalk of southwest Arkansas.

Chalks and chalky limestones also occur within certain Tertiary sequences exposed in the southeastern United States. Principal among these are chalky lithologies found within the Ocala Group of Eocene age in Florida, Alabama and Georgia, and the Oligocene-age Marianna Limestone of Alabama and Mississippi. Generalized stratigraphic relationships for all these units are illustrated in Figure 1 .

Because the Tertiary-age chalk units cited above are less wel.1 developed in both thickness and lateral extent, and commonly occur within carbonate intervals which serve as important groundwater aquifers, their potential within the context of this report is viewed as poor. Likewise, the Cretaceous-age Pecan Gap and Saratoga Chalks are too thinly developed and laterally restricted (Rouse, 1944), and cannot be seriously considered as repository sites.

According to Weeks (1938), the Annona Chalk attains a maximum thickness of 300 feet in southwest Arkansas, making it too thin of a unit for additional consideration. Mellen (1958), however, 


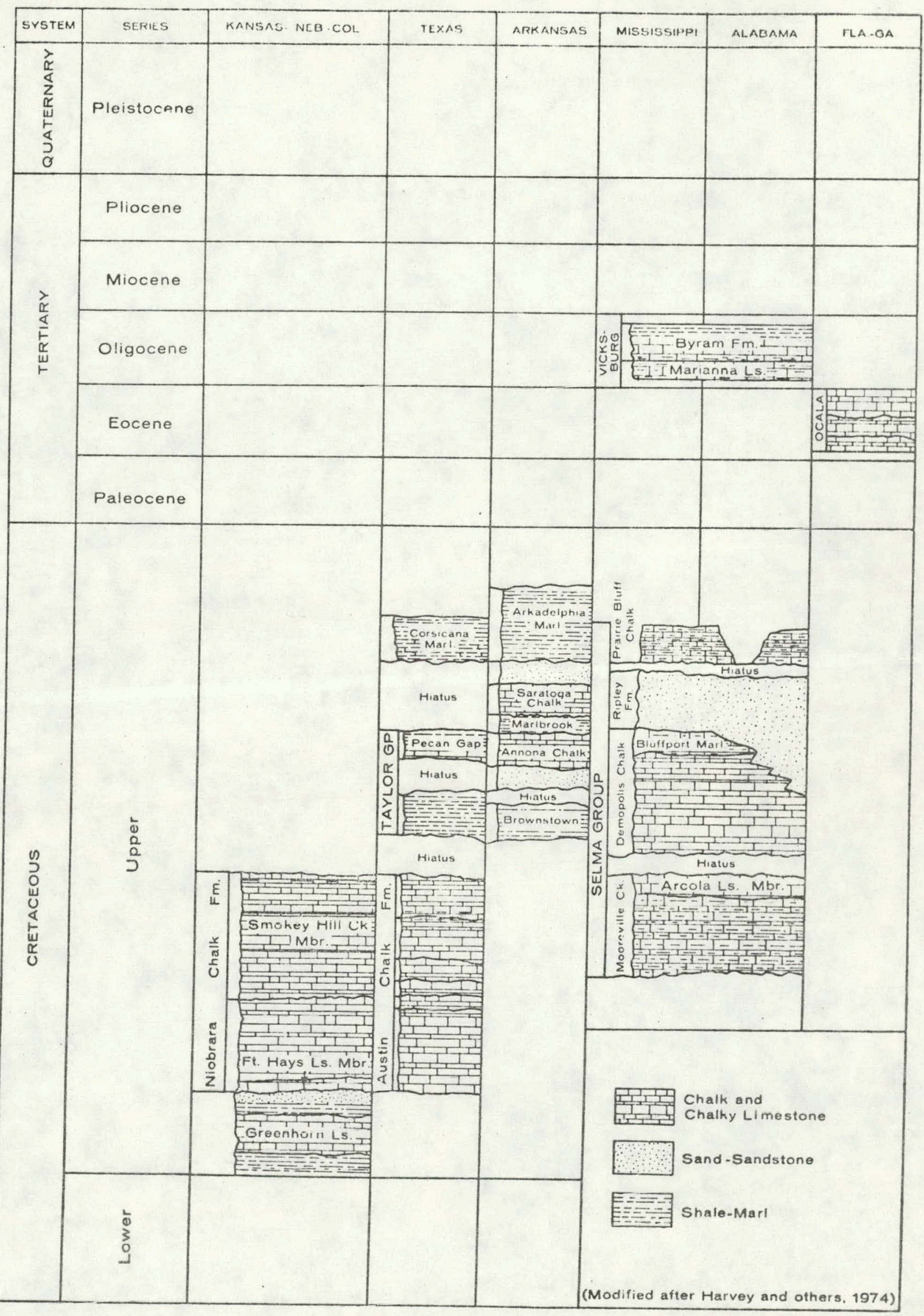

Figure 1. IDEALIZEd GEOLOGIC TIME-ROCK CLASSIFICATION OF CHALK-BEARING STRATIGRAPHIC INTERVALS IN the United States. 
believes that the Arnona Chalk extends into northwest Mississippi where it combines with lateral extensions of the Selma Group. This relationship is discussed in more detail under additional comments about the Selma Group, which with the Austin and Niobrara intervals, will be the focus of subsequent commentary. 


\section{PHYSIOGPAPHIC SETTING}

The chalk-dominated formations discussed in this report are exposed and underlie two different physiographic provinces which nevertheless display a general similarity in both being regions of extensive plains. As illustrated in Figure 2, the Niobrara Formation occurs mainly within the Great Plains province, while the Austin Chalk of Texas and the Selma Group of Alabama and Mississippi are located in the western and eastern Gulf coastal Plain respectively.

Both these physiographic provinces are characterized by relatively gentle topographic expression although several resistant escarpments or cuestas are well developed in each. In all three areas, the inclination (dip) of the chalky sequences and the formations overlying and underlying them is gentle unless complicated by local structure.

Along the Gulf Coastal Plain, strata dip toward and form generally arcuate outcrop patterns around the present-day Gulf of Mexico.. This has produced a "belted" character to the coastal-plain topography, a feature which can be best observed in the eastern section containing the Selma Group (Figure 3). Development of alternating cuestas and lowlands reflects the varying resistance of the sedimentary rocks which underlie the

Coastal Plain. Seaward inclination of the land surface here therefore agrees with the regional dip of the Tertiary and Cretaceous strata.

Thornbury (1964). has observed several contrasting features 


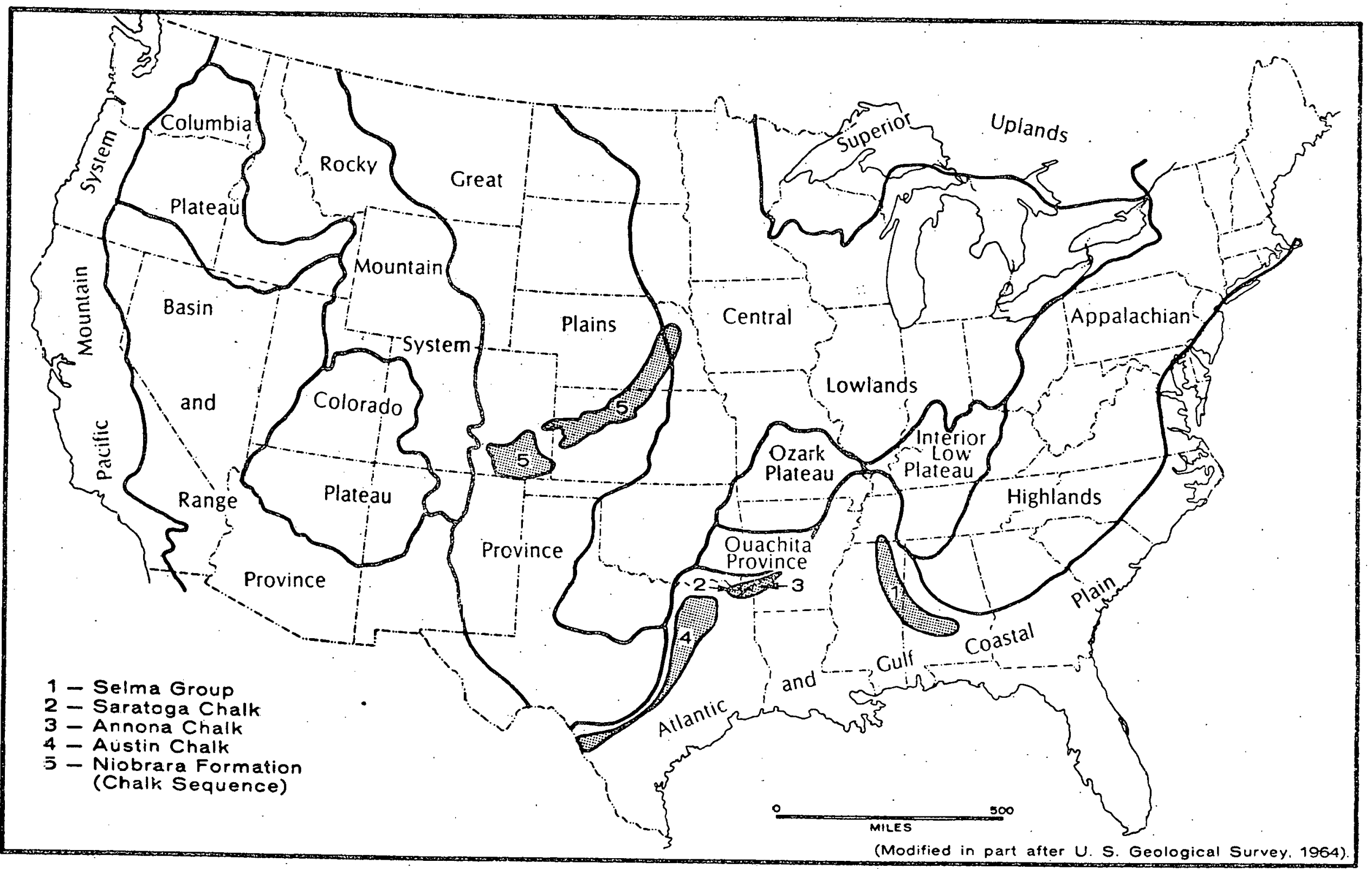

Figure 2. Location of the Upper Cretaceous Niobrara formation, Austin Chalk and Selma Group and SOME MINOR CHALKS WITHIN THE PHYSIOGRAPHIC PROVINCES CONTAINING THESE UNITS, 
between the East and West Gulf coastal Plain. The latter is considerably wider than the former, and displays much larger drainage systems, a more pronounced non-cuesta prairie-marsh zone adjacent to the Gulf of Mexico and a greater degree of structural-geology features. Most prominent among the latter are several zones of faulting and the more numerous occurrence of piercement salt domes. Although these structures receive discussion elsewhere in this report, the effect of the westernmost zone of faulting, known as the Balcones Fault Zone, deserves some comment here. Extending from Uvalde County on the southwest to williamson County northeast of Austin, this zone of southeast dipping and downthrown faults (Weeks, 1945) has created a prominent escarpment which marks the western boundary of the Coastal Plain with extensions of the Great Plains in Texas. From the latitude of Waco along the Brazos River north and northeastward, this physiographic boundary is however marked by the contact between Lower Cretaceous strata and older rocks.

In both the case of the Austin and Selma Group chalks, development of black, calcimorphic soils has given rise to geomorphic units called Black Prairies. Within Texas this unit extends from near Austin to the Arkansas border and is broader than its counterpart in Alabama-Mississippi because weathering of the adjacent, carbonate-rich Taylor and Navarro stratigraphic intervals has contributed to its more extensive development.

As noted in Merriam (1963), the generally eastward inclination of the land surface in central to western Kansas is discordant with strata which are older than Tertiary in age 


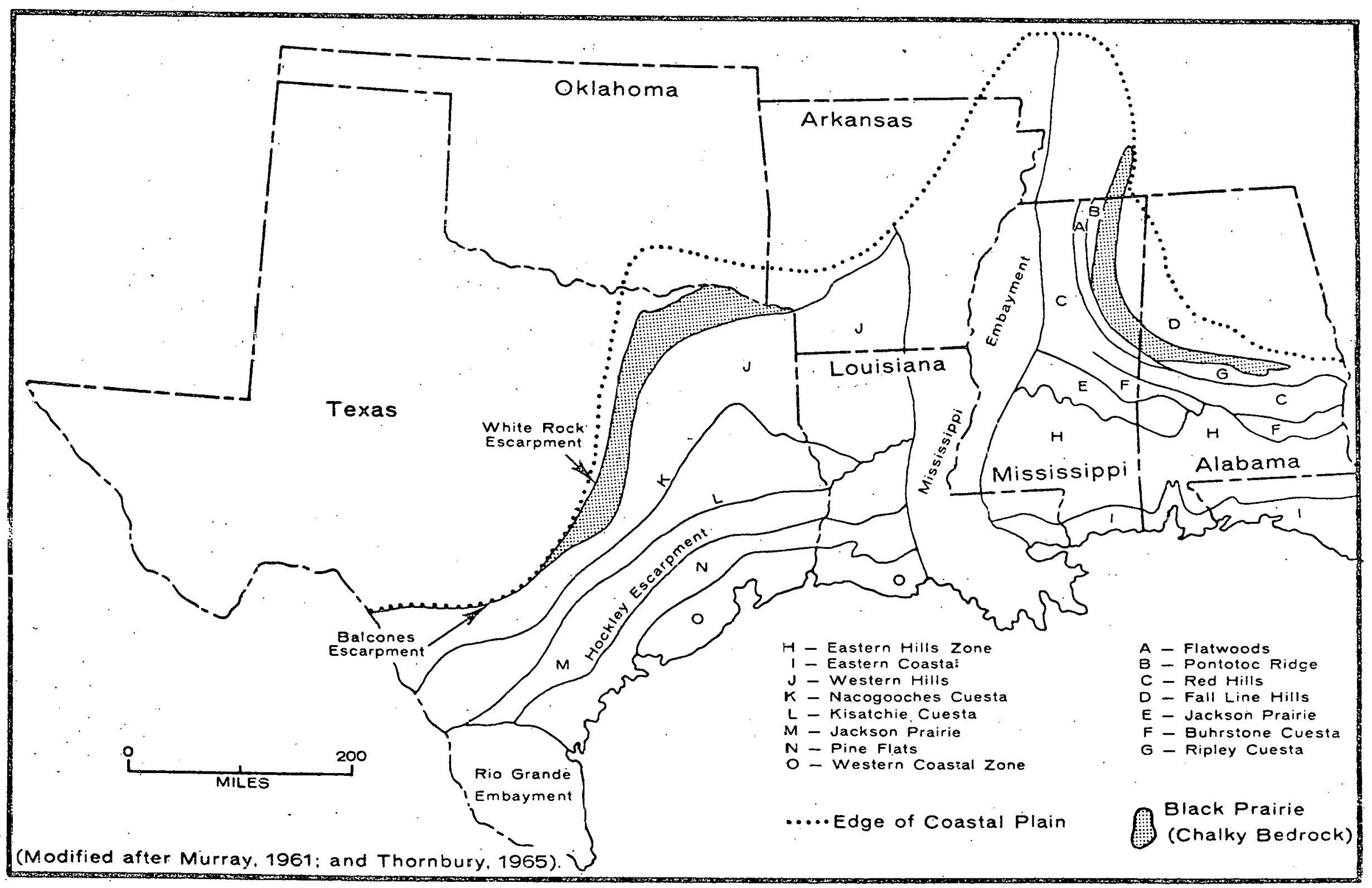

Figure 3. Physiographic setting and topographic belts developed in the East and West Gulf Coastal Plain relative to the outcrop patterns of the Austin Chalk and Selma Group. 
and dip gradually to the west. A similar relationship can be observed from a series of geologic profiles extending from westcentral Nebraska into eastern Wyoring and Colorado as presented by Condra and Reed (1950). Several east-facing, eroded cuestas Iie to the east of the High Plains section and have been formed by westward erosion into Upper Cretaceous units, one of which is the Niobrara Chalk (Fenneman, 1931). Schoewe (1949) has designated this belt the Dissected High Plains, of which the Blue Hills region is developed upon the outcropping Niobrara Chalk. The latter in turn underlies the High Plains to the west where the Pliocene-age Ogallala Formation forms a consequent, eastsloping land surface (Figure 4).

The High Plains province physiographically is on a regional basis a featureless plain which rises steadily from 2000 feet in west-central Kansas-Nebraska to slightly more than 4000 feet by the western borders of these two states. As evidenced by the northeast-southwest, irregularly arcuate outcrop pattern of Upper Cretaceous strata through Nebraska and Kansas, westward erosiondissection has retreated the eastern edge of Cretaceous strata more in south and southwest Kansas: Superimposed upon this regional trend has been the more extensive breaching of the High Plains Tertiary cover (Ogallala Formation) and some Pleistocene sediments by several east-flowing streams. This dissection, which has exposed the Niobrara Chalk along the stream valleys of the Republican River in Nebraska and the Solomon, Saline and Smoky Hill Rivers in Kansas, has been most pronounced along the latter stream. Thus, in a belt extending 


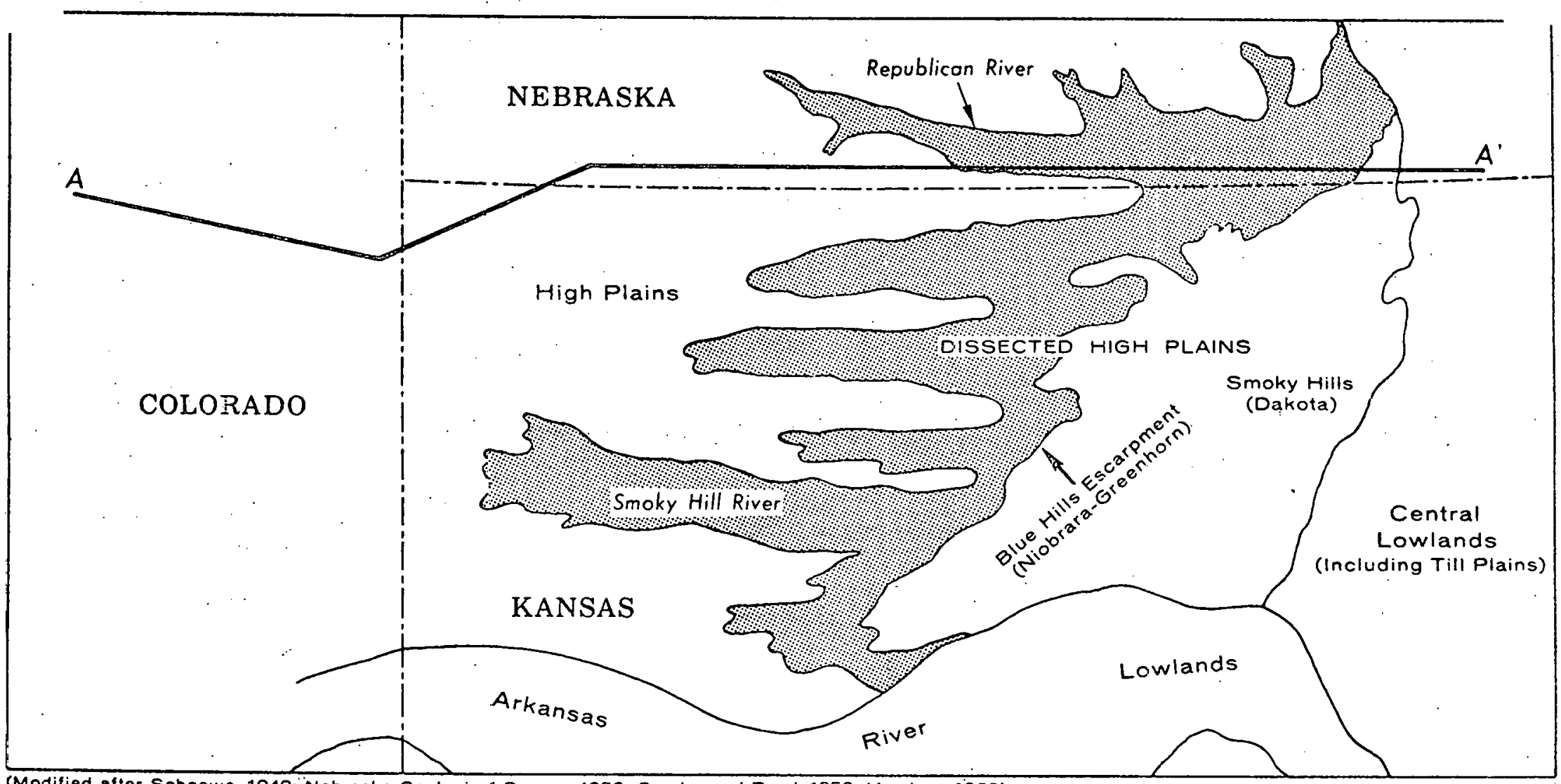

(Modified after Schoewe. 1949: Nebraska Geological Survey, 1950: Condra and Reed. 1950: Merriam, 1963).

50 100 Miles

\% Area Principally Exposing Niobrara Formation

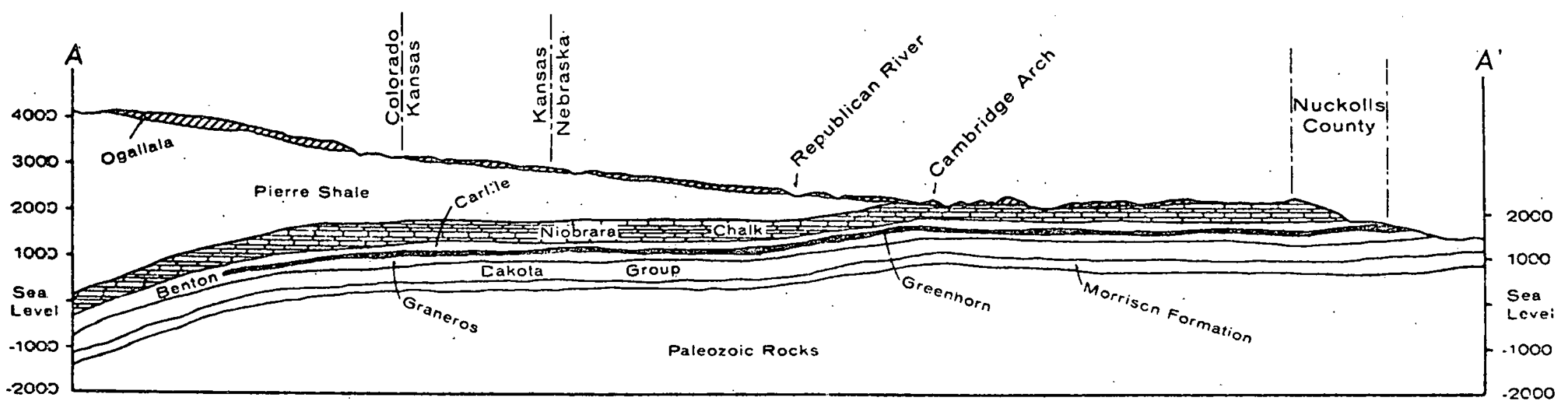

-2000
Fee1

Figure 4. Physiographic setting of the Nlobrara formation hithin the freat Plains showing westward

DISSECTION ALONS EAST-FLOWING STREAMS AND RELATIONSHIP OF WEST-DIPPING STRATA AND

CONSEOUENT, EAST-SLOPING LAND SURFACE. 
westward from Trego County, Kansas to nearly the Colorado border, the Niobrara outcrops farther to the west than elsewhere in the High Plains. In northwest Kansas and southwest INebraska, dissection in places has cut through the Tertiary Ogallala Formation but the land surface remains floored there on the Pierre Shale which immediately overlies the Niobrara Chalk.

Prominent outliers and eroded remnants of the Niobrara Formation can be found in Gove County, Kansas and elsewhere to the east of the present outcrop belt of this chalky sequence. These features provide clear evidence that the Niobrara extended farther to the east in the geologic past.

Structural complications and post-structural erosion near the Black Hills in South Dakota and along the eastern margin of the Rocky Mountain belt in Wyoming and colorado have exposed the Niobrara at the surface. As subsequent discussion in the section on stratigraphy reveals, much of the chalky phases in the formation have been replaced there by more competent Iimestones or shale intervals. 
As can be observed from Figure 5, the principal chalk-bearing sequences discussed in this report are situated in areas of relatively low seismic risk. Much of the Austin Chalk occurs within zone 0 where the incidence of damaging earthquakes is essentially nil. A portion of the Austin outcrop belt does, however, extend into Zone 1 in northeast Texas. The Selma Group and Niobrara Formation both are exposed within areas of seismic-risk zone 1, although the northernmost selma outcrop and its subsurface extensions lie close to the southern border of zone 2 whose dimensions are influenced by the New Madrid seismic belt in southeast Missouri.

By contrast, the previously anticipated repository site at Lyons, Kansas and the currently investigated repository site east of Carlsbad, New Mexico each involves bedded salt horizons lying within seismic-risk zone 1. The Lyons site did, however, lie reasonably near to the western margin of a narrow belt of zone 2 which reflects the somewhat greater occurrence of seismic events along the buried Nemaha Ridge.

Superimposed upon this generally favorable location with respect to zones of low seismic risk is the realization that individual seismic events have been recorded in all the states containing these chalk-bearing sequences (Figure 6). In a positive vein, putentially damaging events, or those producing intensities greater than VII on the Modified Mercalli Scale, have been few, and for the most part generally distant from the outcrop and moderate-depth subsurface position of the stratigraphic 


$$
\text { 5u } 10
$$


units under consideration here. By the end of 1974, only eleven (11) potentially damaging earthquakes had occurred in those states containing these chalk sequences and adjacent states displaying slightly greater seismic activity.

One of these events, near Denver, Colorado, was associated with induced seismicity precipitated by the unadvisable, highpressure injection since 1962 of liquid wastes into a subsurface disposal well located on the Rocky Mountain Arsenal (Evans, 1966; Healy and others, 1968). By virtue of suspending these injection operations in 1968 and subsequent efforts to remove some of the injected fluids, no damaging seismic events have taken place since then, although minor activity has persisted into the early $1970^{\prime} \mathrm{s}$ (Earthquake Information Bulletin, 1970c; Coffman and von Hake, 1973 ).

There has been only one seismic event of intensity VIII in the states shown in Figure 6, and that earthquake took place in extreme southwest Texas, more than 300 miles west of the Austin Chalk outcrop belt. Effects were not felt that far east.

Although no potentially damaging earthquakes have taken place within or near the outcrops of the Selma, Niobrara, or Austin intervals, some intensity $V$ and VI events have occurred in these arcas. Within Alabama, the majority of seismicity has been centered in the so-called South Appalachian zone (Bollinger, 1973). This zone lies well to the northeast of the Demopolis, Alabama area where the Selma chalks are particularly well developed. The most recent earthquake in Alabama was of magnitude 3.9 on the Richter Scale and gave rise to intensity $\mathrm{V}$ responses in a local area some 40 miles north-northwest of Demopolis in 1971. 


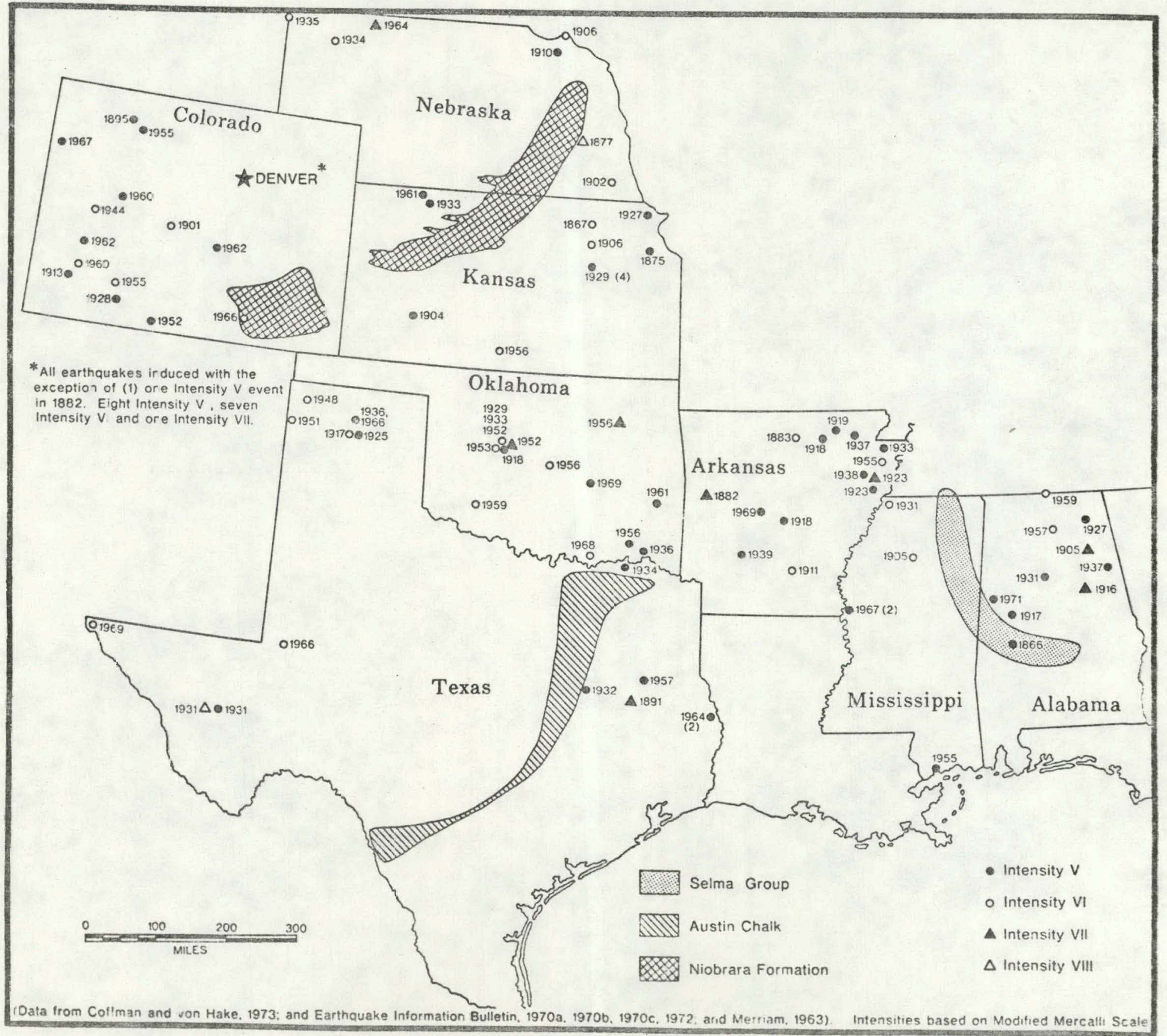

Figure 6. Semi-regional plots of epicentral locations for seismic events abova intensity $V$ in states containing principal chalk-bearing sequences. 
In spite of this and two older, similar intensity events in the Selma outcrop area, the seismicity within the Appajachian trend and felt responses from larger earthquakes outside of Alabama, such as several in the New Madrid Zone, no structural damage to surface features has been detected where the selma chalks are exposed. Integrity of a subsurface LPG facility excavated within the Mooreville Chalk at Demopolis has persisted since 1957 through the local event cited above and two other events in the Appalachian section. None of the infrequent seismic events within Mississippi has exerted any measurable effect on the selma Group (Gonzales, 1975).

Within northeast Kansas, two potentially damaging, intensity VII events plus several less severe earthquakes appear related to possible active faulting along the flanks of the Nemaha Ridge (Merriam, 1963), a buried Pennsylvanian-age structural feature containing a core of domed-up Precambrian granite. This is probably the most significant structural feature in Kansas, extending the breadth of the state into both Nebraska and Oklahoma. The center of this localized seismic activity lies more than 200 miles east of the Niobrara Chalk; felt areas from these events have not been pronounced that far to the west. Two other earthquakes, the first in 1933 and a more recent one in 1961, occurred immediately adjacent to the Niobrara Formation outcrop belt. These events were centered in Norton County, Kansas, and appear related to a gentle anticlinal structure called the Cambridge Arch which extends from Nebraska into Kansas. Both seismic events produced intensity $\mathrm{V}$ responses and no structural damage. Although 
two intensity VII events are known respectively from eastern Nebraska in 1877 and northern Nebraska in 1964, neither is proximal enough to the main body of the Niobrara Formation to be of consequence.

The few seismic events known from eastern Texas occur largely to the southeast of the Austin Chalk outcrop belt. of these, only one, which occurred in 1891 near Rusk, was strong enough to register intensity VII responses. Other earthquakes, occurring in 1932, 1957, and 1964, were all of intensity $V$ rating; two events near Hemphill adjacent to the Louisiana border may have been related to reservoir loading while the 1932 earthquake near Mexia-Wortham may represent movement along graben-like faults in the Mexia Fault zone. The latter is less than forty (40) miles east of the Austin Chalk outcrop belt. Seismicity near the Oklahoma border has also involved the Austin sequence, especially in the vicinity of Paris, Texas where an intensity $V$ event was recorded in 1934. Paris is located within the east-striking Austin outcrop trend in this portion of Texas. Across the Oklahoma border, two intensity $\mathrm{V}$ events, one in 1936 and the other in 1956, and an intensity VI event in 1968 have occurred less than thirty (30) miles north of Austin Chalk exposures. Although the felt areas for all these northeast Texas-southeast Oklahoma earthquakes extended to the Austin interval, no structural damage was observed in the outcrop region.

Despite the occurrence of some low-intensity earthquakes in the general vicinity of the principal upper Cretaceous chalkbearing sequences, the prognosis with regard to favorable seismic conditions in any of the three areas appears very promising. 
By comparison with the strongly orogenic belts at the margins of the North American continent, the Mid-Continent region of the United States is relatively stable tectonically. Extending westward from the Appalachian Mountains to the Rocky Mountains, and northward from the Ouachita Fold Belt and the Mississippi Embayment into western Canada, this extensive region is characterized by a series of structural-depositional basins and intervening domal uplifts. As viewed by Ham and Wilson (1967), the Michigan, Illinois and Midland-Delaware (= West Texas Permian) Basins represent major cratonic basinal structures in this region. Each of these basins contains up to 15,000 feet of Paleozoic-age. strata. Shallow cratonic basins are those containing between 4000 and 8500 feet of sedimentary sequence. Basins of this category include the Williston in North and South Dakota and Montana, the Palo-Duro Hardeman of oklahoma and Texas, the Hugoton of southwest Kansas and the Salina-Forest City of Kansas, Nebraska, and Iowa. Separating these several basins are such uplifted structural features as the Cincinnati Arch, the Ozark Dome, and the Nemaha Ridge. Unconformities and overlapping stratigraphic relations in these principally Paleozoic basins provide evidence of the periodicity with which these structural elements developed in league with platform-type sedimentation.

Although bordering zones like the Ouachita-Arbuckle Trend show intense structural deformation, complex structures within the Mid-Continent Region are rare. Only the Rough Creek Fault Zone of Kentucky and Illinois, adjacent to the New Madrid seismic belt of Missouri, represents an example of pronounced structural deformation. There exist, of course, scattered zones of smaller- 
scale faulting, regional joint systems, individual fault lincaments and localized folded structures. Many of these semi-regional features can be noted on the tectonic map of the United States (American Association of Petroleum Geologists, 1962).

Overprinted on this Paleozoic tectonic framework, especially along the western portion of the Mid-Continent where the Great Plains are now developed, are several Mesozoic and Cenozoic modifications. The latter in large measure are intimately related to the development of the Rocky Mountains. As they have affected the Great Plains area, the following are the most salient: (I) extensive Cretaceous-age sedimentation including deposition of the Niobrara Formation and related units; (2) renewed tectonic movement along certain Paleozoic-age features although this largely ceased by the Cenozoic; (3) formation of new tectonic features such as the Hartsville Uplift, the Las Animas Arch and the Denver-Julesburg Basin; (4) Tertiary erosion of the Rocky Mountains and the widespread alluvial deposition eastward on top of the Cretaceous strata, combined with the gentle eastward tilting of the land surfare.

A characteristic in much of the western Mid-Continent is the relative thinness of the sedimentary cover. As noted in Merriam (1963), stratigraphic sequences rarely exceed 5000 feet in thickness, thin measurably over several uplifted areas, and do not exceed 10,000 feet anywhere within the state of Kansas. In western Nebraska, the sedimentary section ranges from 3000 to 5000 feet in thickness, but does not exceed 9000 feet even at the eastern edge of the Denver-Julesburg Basin (Condra and Reed, 1943). 
Local. structures of import in western Kansas and Nebraska and eastern Colorado include the follwing:

1. The Chadron-Cambridge Arch-Central Kansas Uplift--a series of arcuate, northwest-southeast trending uplifts which extend from south of the Black Hills in northwest Nebraska to the Kansas-Oklahoma border.

2. Hugoton Embayment--as a northwestward extension of the Anadarko Basin, this feature lies west of the structural trend cited above and contains the thickest (9500 feet) sedimentary section found in Kansas.

3. Las Animas Arch--a gentle northeast trending and plunging uplift which barely enters western Kansas and separates the Hugoton Embayment from the Denver Basin in eastern Colorado.

4. Denver-Julesburg Basin--situated along the eastern front of the Rocky Mountain Trend, this basin exhibits north (Julesburg) and south (Denver) centers of deposition; strata thicken westward from the Chadron-Cambridge Arch into this feature.

5. Salina-Central Nebraska Basin--contains nearly 5000 feet of strata with a slight northward plunge, lies to the east of the Chadron-Cambridge Arch-Central Kansas uplift, and is flanked on the east by the Nemaha Ridge; much of the Niobrara Formation now exposed as outcrop was deposited here as well as across the Central Kansas uplift.

Superimposed upon these semi-regional structural features are many subsidiary folds, especially within the buried Paleozoic sequence where many form productive petroleum traps. Joints and faults are also known. Many of the latter have rather subtle expressions, particularly in the younger sedimentary units, and are not even depicted on the state geologic maps of Kansas and Nebraska. A major exception is the Humboldt Fault whose nearly 1000 feet of displacement is evident in southeasternmost Nebraska. There are, however, two zones of regional faulting which can be noted from the Basement Map of North America (American Association of Petroleum Geologists, 1967). One system parallels the north- 
south elongated Nemaha Ridge in eastern Kansas and the other trends roughly parallel to the Central Kansas Uplift-Cambridge Arch in central and northwest Kansas.

With specific reference to the Niobrara Formation in western Kansas and Nebraska, the tectonic setting and structural geology of the Great Plains exhibits several favorable aspects. The more important of these considerations are:

1. gentle westward dip toward the Denver-Julesburg Basin which permits a relatively thick covering of both the Ogallala Formation and the Pierre Shale above the Niobrara in many areas.

2. existence of several thousand feet of stratigraphic sequence, highlighted by an acceptable thickness for the Niobrara chalk-dominated sequence of 500 or more feet.

3. lack of any major complex structural deformation in this general region.

of some concern, however, are the several small faults that have been noted in association with the Cambridge Arch together with numerous small-displacement faults found particularly in surface exposures of the Niobrara Formation. In addition, this formation in several locations has associated with it, again in surface exposure, numerous small joints, some of which are vertical and others of which show an arcuate curvature. Further structures worthy of some comment include several sinkholes and other depressions typical of portions of the Great Plains. The majority generally lie to the south and southwest of the principal subsurface occurrence of the Niobrara. These features have alternately been ascribed to the dissolution of deeper salt or gypsum units, dissolution in carbonate units along faults and/or joints, and other phenomena. Of principal impact with regard to the thick 
subsurface section of the Niobrara Formation is the exact naturo. of any joints, faults and solution features, if the latter actually exist within this stratigraphic interval.

The chalky sequences of both the Austin Formation and the Selma Group are associated with a major regional tectonic feature alternately known as the Gulf Coast Geosyncline or the Gulf of Mexico Basin. Due to a partial assymmetry in the development of this large tectonic feature, the selma Group chalks lie to the northwest of those regional structural elements, namely several zones of large-displacement faulting, which delineate the basin's peripheral boundary with reference to the continent. Contrastingly, the Austin Chalk, both in outcrop and near-surface subsurface sequence, js more intimately involved with several of these bordering fault structures throughout the Texas Coastal Plain.

Because of space limitations in this report, much discussion about the several contrasting views concerning the evolution of this major tectonic feature cannot be considered. At present, however; the two leading schools of thought ascribe alternately to either continental arifting through plate tectonic movement or more conventional basin-crustal downwarp associated with the overall tectonic evolution of the continent. Articles by Meyerhoff (1967) and Paine and Meyerhoff (1970) provide information supportive of the hypothesis favoring the more conventional crustal subsidence-basin development. Information presented by Freeland and Dietz (1971) Eavors the newer concept of genesis, namely plate tectonic evolution for both the Caribbean and Gulf of Mexico regions. Inasmuch as the intent of this report is to 
discuss regional tectonic features related to the outcrop areas of Upper Cretaceous chalk units, no additional commentary about resolving these contrasting genetic mechanisms is planned.

On a regional basis, a number of significant characteristics adequately frame the tectonic setting of the Gulf of Mexico for the stratigraphic sequences of interest. These tectonic characteristics include: (I) deposition of basin-thickening stratigraphic sequences, dominated by clastic material, which attain aggregate thicknesses upward of 30,000 to 40,000 feet in the thickest portion of the basin; (2) formation of stratigraphic sequences over a variety of basement complexes even though the majority of surfaces represent eroded, deformed paleozoic rocks of the Appalachian-Ouachita tectonic province; (3) extensive flexure faulting along the basin's periphery by which the tectonic boundaries are essentially established; (4) considerable additional faulting of both down-to-the-basin and graben character; many of these faults represent so-called growth faults in which stratigraphic sequences on the downthrown side are enlarged over those on the upthrown side; (5) extensive salt-related tectonics which include the offshore Texas-Louisiana, East Texas Embayment and Central Mississippi Interior Salt dome provinces, plus other saltrelated structures which include deeply-buried salt ridges, and anticlines and faults due to removal-migration of salt; (6) development of several positive tectonic areas such as the San Marcos Arch, and Sabine, Monroe, Wiggins, and Jackson Uplifts, and associated intervening synclinal features including the Desha Basin and East Texas Embayment; (7) intrusion of several different kinds 
of generally cretaceous-age igncous rocks, especially those arsociated with the Balcones Fault Zone in southwest Texas and tho: unassociated with faulting throughout northern Louisiana and Arkansas.

In view of the great degree of tectonic complexity and numerous structural-geology features found in the Gulf of Mexico region, thorough discussion of this situation is not possible here. For a detailed treatment and synthesis of these topics, the reader is referred to the excellent reference by Murxay (1961). On a more Iimited basis, some summary comments about the effects of these structural-tectonic elements on the Austin and selma intervals is instructive.

1. Because of the outline of the Basin and the resulting arcuate outcrop patterns, the strike for both sequences varies depending upon location.

2. Both sequences are inclined toward the Gulf of Mexico at regional dips from 40 to 80 feet per mile (Stephenson, 1918; Deussen; 1924). Local deformation by faulting, domal uplifts or salt-dome intrusion can markedly change these gentle inclinations to steeper dips.

3. Because the Selma Group lies to the north and northeast of the Gilbertown-Pickens border fault system, it is less affected by regional faulting than the Austin, which has been appreciably cut by the faults of the Balcones, Luling and Mexia systems (Weeks, 1945).

4. Aside from minox displacements along joints, the only prominent faulting to affect the selma is the unusual zone of mainly reverse faults known as the Livingston zone; this not fully understood disturbance extends from south of Demopolis in a northwest arcuate trend to as far north possibly as Macon, Mississippi; the possible mechanisms responsible for this faulting and its relationship to the Selma are treated by Gonzales (1975).

5. The Austin Chalk markedly thins over the San Marcos Arch and is truncated against the Sabine Uplift; in its downdip extension, the Selma Group is truncated against the Jackson Uplift (Mellen, 1958). These and other structures may be related to renewed movement on Paleozoic features or Mesozoic intrusive activity or both (Durham and Murray, 1967). 
6. Salt domes intrude and in some places even bring to the surface the Austin interval (Texas Bureau of Economic Geology, 1967; American Association of Petroleum Goologists, 1973); these domes are located within the East Texas Embayment; downdip selma Group equivalents may also be affected by salt domes of the Interior Mississippi Province.

7. The Austin is also affected by numerous linear to arcuate belts of faulting and attendant folding throughout its southwest-northeast extent in Texas.

8. Although fractures and joints are visible in outcrop for both chalk sequences, the surface exposures of each unit lie slightly beyond the zone of aistinctly regular fractures typical of the area adjacent to the Mississippi Embayment. 
For the sake of brevity, the historical background behind the derivation of the stratigraphic units Niobrara Formation, Austin Chalk, Selma Group and its included Mooreville, Demopolis and Prairie Bluff Formations will not be reviewed here. A thorough discussion on the Selma Group can be found in Gonzales (1975) and information on all these units is contained within Keroher and others (1966). In a similar vein, articles by Stephenson and others (1942) and Cobban and Reeside (1952) provide extensive information on the geologic correlations and facies equivalents for all Cretaceous strata exposed in the Western Midcontinent and along the Atlantic and Gulf Coastal plains. The Niobrara Formation, as indicated on Figures 1 and 2, is best exposed throughout Nebraska, Kansas and eastern Colorado. Although the chalky sequence and its lateral equivalents are known from other areas throughout the western interior, this region exhibits the more favorable elements of the formation. Resting disconformably upon the Carlile shale, the Niobrara varies in total thirkness from 450 to in excess of 700 feet. Isopachous mapping by Merriam (1963) indicates the formation is not less than 500 feet in northwestern Kansas. As can be seen from the cross section in Figure 4 , it is overlain by the Pierre Shale whose thickness increases westward into eastern colorado to where it exceeds 1500 feet. In northwest Kansas, the Pierre thins to its outcrop edge.

The Niobrara consists of two prominent divisions, the basal Fort Hays Member and the much thicker Smoky Hill Member. The 
former is a laterally persistent (Frey, 1972) unit reaching a maximum thickness of 80 feet. It consists mainly of thick beds of chalky limestone with thin interbeds of chalky shale and some pure chalk zones. Overlying this unit is from 400 to 650 feet of impure shaly chalk and chalky shale, although some thick, persistent chalks also occur. Some would designate much of this member's lithology as marl as opposed to chalky shale (Dane and others, 1936). There are several zones of bentonite and much of the claymineral assemblage is montmorillonitic. Minor amounts of gypsiferous material, jasperoid layers and calcareous clay-shale are present. As noted previously, joints and small displacement faults plus some minor collapse features characterize the Niobrara. By the time this unit comes to surface on the west side of Las Animas Arch near Pueblo, Colorado, it has lost a fair measure of its chalky character and is more shaly (Scott and Cobban, 1964). Chalk units still persist at several intervals. Further to the west, the Niobrara interfingers into the fine-clastic Mancos Shale. Northwara into Nebraska and the Dakotas, the Niobrara thins to between 100 and 200 feet, merges into more shale-dominated sequences, and is often mapped with other Upper Cretaceous units under different stratigraphic designations.

The northwest Kansas, southwest Nebraska and northeast Colorado region contains the most expression of the Niobrara for purposes of this repository consideralion. Here, it is thick, dominated by chalky lithologies, relatively undisturbed structurally, gently dipping, overlain by a thickening impermeable shale, reasonably accessible in the subsurface, and sufficiently removed 
from its outcrop in central Kansas to minimize fears of lateral retreat-ajssection.

At its type section near Austin, Texas, the Austin Chalk is 410 feet thick and consists principally of white chalky limestone and chalk interstratified with softer units of marl. The formation has been interpreted as lying conformably upon the Eagle Ford Shale here (Stephenson and others, 1942), although in other localities there is either no discernible break or the relationship is a conformable one. Throughout its extent, the Austin lies above this particular shale unit.

In an unpublished doctoral thesis by Professor Clay Durham of Louișiana State University, an effort was made to divide the Austin into several discrete members such as the Dessan and Big House Chalks and Burditt Marl. Other informal divisions have been used by local geological associations, but none of these divisions has received widespread acceptance.

Because of erosion, the Austin thins markedly by the latitude of Waco to a range of 150 to 300 feet (Texas Bureau of Economic Geology, 1970). Similarly, the formation also thins over the San Marcos Arch. In the Dallas area, the unit has again thickened, reaching a maximum thickness of nearly 500 feet (Texas Bureau of Economic Geology, 1972). To the northeast toward oklahoma and Arkansas, the chalky phase begins to laterally disappear as the Austin grades into shales, sands and clays, although upper and lower tongues of chalky material persist further east (stephenson, 1918). The exact relationship of these tongues and some younger chalks, namely the Pecan Gap in Texas and the Annona Chalk further 
east in Arkansas, have been debated in the literature (Stephenson, 1918; Weeks, 1938; Rouse, 1944). Inasmuch as resolution of these different views here would be impractical, suffice it to say that the Austin Chalk has changed laterally in more clastic-dominated intervals, and that the several chalky units found in Arkansas are either too thin, too restricted, or too vertically inconsistent to warrant serious consideration as potential repository sites.

Throughout the principal outcrop extent of the Austin, chalky lithologies with interbedded marls are typical within a thickness. of 300 to more than 500 feet. Bentonitic material and thin seams of bentonite occur in most well-exposed localities. Everywhere along its outcrop, the Austin Chalk is disconformably overlain by Taylor-age strata, usually marls or more competent limestones. This in part explains the wider belt of black prairie soils developed in Texas as opposed to Alabama and Mississippi.

The Selma Group is divided into three distinct formations; namely the basal Mooreville which has the distinctive resistant Arcola Limestone at its top, the Demopolis Chalk containing a partially discernible marl member near its top and a much less well developed upper unit, called the Prairie Bluff Chalk. These units, their disconformable relationships with each other and their overall lateral stratigraphic relationships are depicted on Figure 7 . These intervals contain a mixture of thick pure chalk units, chalky limestones, typified by the Arcola, chalky shales or marls and some shaly interbeds. Although the Mooreville thickens in a eastward direction from western Alabama, it is in this latter area where the aggregate thickness of the Moorevj.1le and Demopolis is 


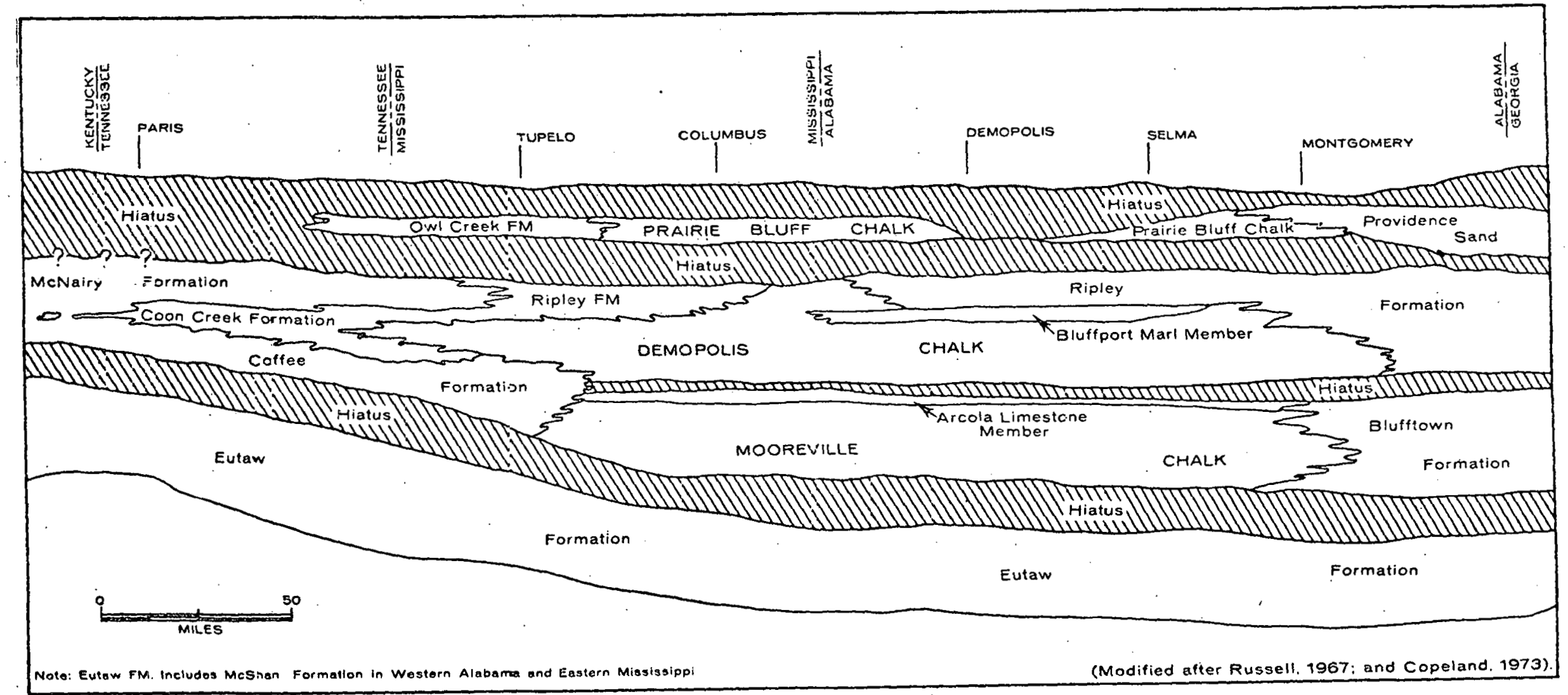

Figure 7. Generalized stratigraphic relations of the Selma Group formations from eastern Alabama to southern TenNessee. 
the greatest. Here, these two units vary from 700 to 800 fect in total vertical extent (Newton and others, 1961). Westward into Mississippi, thinning occurs, and by southern Tennessee, the chalky phases have decreased to a feather edge. Both in a northwest and an eastern direction, as shown on Figure 7, the thick chalk interval of the Selma grades lateraliy into equivalent clastics. Into central Mississippi, Mellen (1958) believes the Demopolis is joined by eastward extensions of the Annona Chalk from Arkansas. Although chalk does occur in the subsurface on the western flank of the Jackson Uplift, confirmation of this contention can neither be shown nor disproven.

Like the Niobrara and the Austin, thin zones of bentonite have been reported from the Mooreville Chalk. These montmorillonitic units would, however, seem to be less numerous in this interval. By virtue of its thinness, erratic lateral distribution as the result of exosion, and more sandy-silty character, the Prairie Bluff Chalk is not consicered to have a viable potential for repository storage. Rather, the thick, adjacent Demopolis and Mooreville sequences in western Alabama and eastern Mississippi appear much more promising. 


\section{HYDROLOGY}

\section{Surface Water}

In all three cases of the Niobrara, Austin and Selma sequences, the regional surface drainage would not appear to pose any appreciable threat to the subsurface extent of these units by virtue of excessive dissection. Only in the region of the Selma Group, where major through-flowing rivers such as the Black Warrior and Tombigbee have cut prominent bluffs into the chalk, is stream erosion pronounced. Of course, relief is appreciable along some Kansas rivers as they breach the prominent cuesta formed by the resistant, gently dipping Niobrara Formation.

Streams, such as the Republican in Nebraska and the Solomon, Saline and Smoky Hill in Kansas, flow in relatively straight paths west to east across the High Plains, although some minor abrupt turns may be partly joint-fault controlled. Although dissection has exposed the Niobrara westward to an appreciable degree, downcutting into the bedrock has not been pronounced. In this semiarid climate, stream flows are generally low to intermittent, and several streams display a braided character with attendant sandgravel deposition. Erosion has been this effective despite low water flows because of the relatively non-resistant nature of the partially consolidated Ogallala. Because the overlying Ogallala Formation is especially porous, much rainfall infiltrates rather than joining overland runoff. Springs emanate along certain areas where the permeable Ogallala is exposed in contact with the Pierre Shale, and thus serve as points of ground-water discharge. 
The Texas Coastal plain features several streams which filow considerable distance across this geomorphic province, having in several cases originated in the adjacent High plains. Thus, the Trinity, Brazos, Colorado and San Marcos Rivers flow across the entire width of the Austin Chalk, as well as the several other coastal-plain cuestas. As such, the areas of drainage are large, but, despite some bedrock exposures and resistant bluffs, the streams have not shown appreciable downcutting capability. The Sabine and Red Rivers have their headwaters located in the Austin outcrop belt. These several rivers form relatively large coalescing deltas and terraces along the coast as a result of their moderate profiles and large sediment loads.

In Alabama, streams flowing across the Selma Group outcrop are few and generally small. These features are a direct response to the impermeable chalk which prevents much discharge to the strears. Pronounced downcutting into the Demopolis Chalk appears related to a form of $\mathrm{Pleistocene} \mathrm{superposition.}$

Schneider and platt (1974) present data to suggest that an average rate of exosion for the country due to river processes is nearly 200 feet per million years. High-range values could reach as much as 550 feet per million years. Assuming a needed cuntainment time of 250,000 years, the range of expected stream erosion-downcutting for that interval would lie between 50 and 140 feet. Although individual stream-valley changes can be much more pronounced than these values, evidence does not support the notion that any stream flowing over these three chalk sequences would exceed the maximum rate. In the Kansas area, a predictive study 
by Stewart and Dort (1973) suggests maximum denundation for the same time interval to be slightly more than 200 feet. Schumm (1963) estimated cuesta-escarpment retreat for semi-arid regions to approximate a maximum of 165 feet in a quarter of a century. Thus, lateral retreat, in the case of the Niobrara, and vertical denundation, in the case of all three sequences, would not appear to pose a problem for a repository several hundred feet within a chalk unit with several hundred additional feet of overburden.

\section{Ground Water}

Because of its pronounced impermeability unless fractured, chalk and related chalky lithologies do not make favorable groundwater aquifers. Evidence for the above restriction other than the near total lack of productive wells in these rocks is: (1) virtually no bank-storage return to streams; (2) persistent dryness experienced by excavated subsurface caverns; (3) minimal seepage from joints at the land surface; and (4) effective aquiclude response in artesian systems.

In none of the geographic regions under consideration does the chalk-dominated sequence serve as a viable ground-water source; however, in all cases, important aquifers lie in reasonable proximity to the chalk formations. Arnow (1963), however, reports that the Austin Chalk in the general San Antonio region does supply ground water, and in some cases appreciable yields, for local use. In this area, and several adjoining ones studied by the U. S. Geological. Survey in conjunction with the Texas Board of Water Engineers, the Austin hydrologic productivity appears 
related to solution porosity and secondary openings along joints and fractured silica-rich intervals. Of interest here is the fact that the Austin interval is much thinner than to the northeast and contains a larger pexcentage of competent limestone units. In this region of Texas, the most significant aquifers are Lower Cretaceous carbonate aquifers of the Georgetown-Edwards-Comanche Peak interval. The latter units are recharged from the west and lie nearly 200 feet stratigraphically below the Austin.

Within the Gulf Coastal Plain of Texas several other stratigraphic intervals serve as important ground-water aquifers, and because of favorable structural and stratigraphic features, many are artesian. Sundstrom and others (1948) list the Trinity (also called Travis Peak) and Woodbine sands as the most important, Upper Cretaceous aquifers. Both these units are stratigraphically below the Austin Chalk, and commonly require wells from 1000 to 3000 feet in depth to tap them. These sands are under artesian pressure but require supplemental pumping to supply large volumes. Lying stratigraphically above the Austin are a number of Tertiaryage aquifers, of which the wilcox and Carrizo sands are among the more important and lie in relatively close proximity to the Austin. Other Tertiary aquifers, such as the Sparta and Catahoula sands, are more important farther to the east in the coastal plain, but lie appreciably above the subsurface position of the Austin Chalk. Recent-age alluvium and other surficial deposits are locally important ground-water sources.

In a zone immediately east of the Austin outcrop belt, or in a narrow $V$-shaped wedge of terrain extenaing northeast from 
Williamson County (north of Austin, Texas) through Navarro, Van Zandt, Hopkins and Lamar Counties to the oklahoma border, ground water is generally unsuitable for use. Most water supplies here are based on surface sources such as the Trinity River, other streams or man-made impoundments. Although some local use is made of ground water in this trend, most porous-permeable zones contain highly saline waters.

In a similar fashion, the two major chalk formations of the Selma Group do not serve as aquifers, but must be penetrated by deep wells seeking fresh water from either the Tuscaloosa or Eutaw Formations. Near the general Demopolis-Marengo County arca in west-central Alabama, where the Selma Group chalks are best developed, wells up to 1000 feet in depth are principally directed to the Eutaw Formation (Newton and others, 1961). Some wells attempting to tap the Tuscaloosa have found the water highly mineralized. The Eutaw lies disconformably below the basal Mooreville Chalk, whereas the Tuscaloosa is stratigraphically below the Eutaw. Some minor water in western Alabama is derived from the Ripley Formation, a unit stratigraphically equivalent to some of the Selma Group.

Studies within northwestern Kansas, specifically Norton (Frye and Leonard, 1919), Gove (Hodson and Wahl, 1960), Wallace (Hodson, 1963), Trego (Hodson, 1965) and Decatur (Hodson, 1969) Counties reveal the following points about ground-water.conditions there:

1. The Niobrara Chalk is not important as an aquifer and generally does not yield nor effectively transmit water. 
2. The Niobrara Formation may yield very smaliz quantities of commonly mineralized water where wells tend to intersect porous silicified zones, joints or minor solution cavities; the quantities are insignificant.

3. The Pierre Shale which immediately overlies the Niobrara similarly yields no water and acts as an effective aquitard to the downward movement of water from overlying water-bearing units; slight quantities of water may exist along bedding surfaces, joints or faults, but none of these effectively breach the unit.

4. The Pliocene-age Ogallala Formation, consisting mainly of porous sands and gravels, is the principal bedrock aquifer and lies stratigraphically on top of the pierre shale; it yields significant volumes of ground water upon pumping.

5. Additional ground water is obtained from surficial deposits such as stream-valley alluvium, terrace deposits and various unconsolidated pleistocene sediments.

6. Some minor amounts of ground water are derived from deeper stratigraphic units, namely the Codell Sandstone Member of the Carlile shale and the Dakota Formation; the foimer lies airectly below the basal member of the Niobrara while the Dakota occurs several hundred feet lower in the section; water within the Dakota is mineralized in some areas.

7. With the exception of some limited water entering the basal Fort Hays Limestone of the Niobrara from the underlying codell sandstone, effective communication between any of these ground-water aquifers and the Niobrara as a whole does not exist.

Within adjacent Nebraska, Condra and Reed (1.936) report similar findings, namely that neither the Niobrara Formation nor the overlying pierre shale yield ground water. Principal aquifers in west-central to western Nebraska include the Ogallala Formation and various unconsolidated surficial deposits. Further to the northwest, ground water is also obtained from sandstone lenses in the oligocene-age Chadron Formation and from several sandy horizons within the Miocene-age Arikaree Group. Both these stratigraphic units lie below the Ogallala Formation, but above the Niobrara 
Formation except where structural deformation in extreme nortines: Nebraska along the east flank of the Hartville Uplift has placed the chadron in direct contact with the Niobrara, 
MINERAI RESOURCES

Being relatively high in their content of calcium carbonate and commonly situated close to or at the land surface, chalks make excellent sources of limestone for use in the manufacture of portland cement and the production of lime. The majority of chemical analyses presented by Runnels and Dubins (1949) indicates that the calcium carbonate content of the Niobrara exceeds 90 percent. Data presented by Harvey and others (1974) also show that several samples of the Niobrara Chalk analyzed by them averaged more than 92 percent calcium carbonate. Similarly, three analyzed samples of the Austin Chalk contained more than 86 percent, and several sources cited by Gonzales (1975) list the range of composition for the Demopolis Chalk in the Selma Group of western Alabama as from 78 to 83 percent calcium carbonate. The relative softness of these chalks and the ease of surface mining have combined with this high purity to give rise to several active quarries in the respective outcrop areas (Table 1). Although somewhat removed from the areas under consideration in this report, the Fort Hays Member of the Niobrara Formation is also quarried for portland cement at Boulder, Colorado (Hardy, 1970).

Although these quarries are man-made breaches into these several stratigraphic units, the depths and lateral dimensions of these open-pit operations are relatively limited compared to the total outcrop extent in each case. A major factor in locating cement-Iime quarries is the surface exposure of the target limestone resource. Thus, in this regard, these excavations represent relatively minor extensions to natural geologic processes, and do 
TABLE 1. Active Limestone Quarries Within the Austin, Niobrara, and Selma Chalks.

\begin{tabular}{|c|c|c|}
\hline Chalk Formation & State/location & Operating Organization \\
\hline \multirow{4}{*}{$\begin{array}{l}\text { Austin Chalk } \\
\text { (commonly mined } \\
\text { with either Eagle } \\
\text { Ford or Taylor } \\
\text { marl-shales if } \\
\text { portland cement } \\
\text { being made) }\end{array}$} & $\begin{array}{l}\text { Bexar County, } \\
\text { Texas }\end{array}$ & $\begin{array}{l}\text { Kaiser Cement and Gypsum } \\
\text { Corp. } \\
\text { Capitol Aggregates, Inc. }\end{array}$ \\
\hline & $\begin{array}{l}\text { Dallas County, } \\
\text { Texas }\end{array}$ & General Portiand Cement Co. \\
\hline & $\begin{array}{l}\text { Ellis County, } \\
\text { Texas }\end{array}$ & $\begin{array}{l}\text { Texas Industries, Inc. } \\
\text { Gifford-Hill Portland } \\
\text { Cement Co. }\end{array}$ \\
\hline & $\begin{array}{l}\text { McLennan County, } \\
\text { Texas }\end{array}$ & $\begin{array}{l}\text { Universal At Jas Cement } \\
\text { (Div.-U. S. Steel Corp.) }\end{array}$ \\
\hline Niobrara Chalk & $\begin{array}{l}\text { Nuckolls County, } \\
\text { Nebraska }\end{array}$ & $\begin{array}{l}\text { Ideal Cement Co. (Div.- } \\
\text { U. S. Steel Corp.) } \\
\end{array}$ \\
\hline \multirow[t]{3}{*}{$\begin{array}{l}\text { Selma Group } \\
\text { (Demopolis Chalk) }\end{array}$} & $\begin{array}{l}\text { Marengo County, } \\
\text { Alabama }\end{array}$ & Lone Star Industries, Inc. \\
\hline & $\begin{array}{l}\text { Noxubee County, } \\
\text { Mississippi }\end{array}$ & $\begin{array}{l}\text { Mississippi Department of } \\
\text { Agriculture and Commerce }\end{array}$ \\
\hline & $\begin{array}{l}\text { Lowndes County, } \\
\text { Mississippi }\end{array}$ & $\begin{array}{l}\text { United Cement Co. (Div.- } \\
\text { Texas Industries, Inc.) }\end{array}$ \\
\hline
\end{tabular}

(data modified after II. S. Bureau of Mines, 1972, and other sources) 
not violate the integrity of a more deeply buried repository site. Evidence supporting this view is available from the Demopolis, Alabama area where a surface quarry has in no way jeopardjzed a nearby LPG facility 300 feet below the surface.

Chalk has also been used locally as a building stone. Risser (1960) reports that both members of the Niobrara Formation have been quarried extensively in small operations throughout western and northwestern Kansas, and the easily worked chalks and chalky limestones have been cut and used to face numerous one- and two-story buildings. Because of the ease in quarrying and finishing, pleasant color and texture and durability in a dry climate, the quarried chalky units are well received as a construction material. Many of the buildings on the Fort Hays State College campus are faced with the Niobrara. Because the quarries are generally small, limited to readily exposed outcrop areas and of intermittent operation, they do not pose any threat as man-made excavations to the possible repository use of the Niobrara. Chalks in Texas and Alabama appear not to have been used to any degree as building stone.

Due to very low permeabilities, chalks, shaly chalks and chalky limestone generally do not make acceptable reservoirs for the entrapment or transmission of subsurface fluids. Where secondary porosity-permeability has been introduced by structural fracturing, fluids such as petroleum can accumulate. For example, the shallower producing horizon in the Gilbertown, Alabama oil field is fractured selma Chalk. Likewise, the selma shows a similar relationship within part of the pickens field in west- 
central Mississippi. Another example involves the Austin Chalk, which in the shallow Mount Calm fjeld northeast of Waco, Texas, is faulted by two normal faults, and the resulting fracturedbrecciated chalk on either side of the more northwest fault has yielded commercial amounts of oil.

A more dramatic petroleum-related occurrence involving the Austin Chalk, however, is the prolific East Texas field. The latter, based on cumulative oil produced to date, is the largest oil field in the United States. Here, the oil-saturated Woodbine Sand of Upper Cretaceous age is arched up against the western flank of the Sabine Uplift, and with angular unconformable relations overlain by the Austin Chalk (and some Eagle. Ford Shale). The chalk's impermeability has made an effective sealing mechanism for this huge accumulation of petroleum. The Austin Chalk is also involved in other petroleum fields within Texas. For example, the Luling field, in Caldwell County northeast of San Antonio, is developed along fold and fault closures caused by high-angle normal faults of the Luling Fault system. The faulted stratigraphic interval overlying the productive lower Cretaceous zones includes the Austin Chalk, although the unit in this case is neither productive nor the effective seal for entrapment.

By virtue of its stratigraphic position, the Austin Chalk is affected by many oil-productive structures in the western GuIf Coast. Although not a significant reservoix unit, the Austin Chalk is folded, faulted, and uplifted along salt domes in this region. In fact, because of its recognizable lithologic character and distinctive response on well-logging records, the Austin 
Chalk commonly serves as a structural-mapping datum in many petroleum fields. As might also be surmised, the Austin sequence has been penetrated by thousands of wellbores in the search for petroleum.

No effort has been made here to study in detail the many specific structural relationships which involve the Austin Chalk in the subsurface. Neither has any attempt been made to catalog the numerous wellbores which penetrate this unit. In addition to the many exploration and development oil wells, there are also these penetrations: salt-water injections and secondary recovery wells to deeper horizons, industrial disposal wells and water wells near the unit's updip extensions. Any in-depth assessment of the Austin Chalk would surely need to consider at length the role of these geologic and man-made relationships although in some cases the Austin is too deeply buried to be considered in the first place.

To a lesser degree, the far downdip selma Group chalks in southwest Alabama and east-central to southeast Mississippi also occur within stratigraphic intervals penetrated by petroleumrelated wellbores. Although the selma is commonly too deeply buried in some of these areas for further consideration, no compilation of wellbore penetrations was possible at this time. The Niobrara Formation does not, in Kansas and Nebraska, constitute an important unit with respect to petroleum geology. As portrayed on the oil and gas map of Kansas (Kansas Geological Survey, 1974), the majority of petroleum accumulations are associated with the Nemaha Ridge, Hugoton Embayment and Central Kansas 
Uplift, and relatively few fields occur in the northwestern part of the state. Although some productive zones below the Niobrara have been found in this area, and other exploratory drilling has been conducted, the number of penetrations here is decidedly less than with regard to either the Austin or Selma units. Again, however, no inventory of the exact number or location of these boreholes could be made for this report.

Although potable ground water does not occur in chalkdominated sequences, desirable aquifers above and below the chalk units of interest here are tapped for water. This condition has been previously treated in sufficient detail to preclude additional commentary here.

other mineral resources are known to occur stratigraphically above or below chalk sequences. In the Eocene-age Wilcox sequence of east-central and northeast Texas, mineable bodies of lignite are widely dịtributed (Kaiser, 1974). Some deposits are presently strip mined for this energy resource, but the surface openings do not pose a hazard to the more deeply buried Austin. salt is another resource which ocours in proximity to chalk deposits. As shown by Hardy (1970), Permian-age salt horizons underlie much of west-central and western Kansas, and therefore lie below both the outcrop belt and subsurface extensions of the Niobrara Formation. Commercial recovery by both solution and conventional underground mining is confined to the easternmost extent of this trend. This area is located some 200 to 250 miles east of where the Niobrara Formation dips below the Ogallala Formation and Pierre Shale in northwestern Kansas and southwestern 
Nebraska. As such, mining of this salt poses no adverse situation to the potential. repository use of: the Niobrara.

In several places along the Coastal Plain of Texas, salt occurs in massive salt domes which have intruded the stratigraphic sequence containing the Austin Chalk. Recovery of salt is underway in several of these structures by either room and pillar underground methods or solution mining. Some domes in this category lie appreciably down dip with regard to the subsurface Austin Chalk; however, the Grand Saline Dome in Van Zandt County occurs only 50 miles east of the Austin outcrop belt. Several salt domes are also used for the cavern storage of LPG. Those domes known as Hainesville, East Tyler, and Butler each serves as an LPG storage site (Hawkins and Jirik, 1966), and all intersect the Austin Chaik at depth. As noted previously, Brooks, Palestine, Oakwood, and Butler Domes even bring Upper Cretaceous strata including the Austin interval to the surface (Texas Bureau of Economic Geology, 1967; American Association of Petroleum Geologists, 1973). Thus, both from economic and structural-geology viewpoints, these salt domes and man's use of them have an impact on the Austin Chalk. The Mooreville Chalk of the Selma Group is itself utilized as an LPG storage horizon, thus indicating another economic use for chalk. The facility is located east of Demopolis, Alabama and has been in operation since 1957. Two large storage caverns excavated within the 300 foot-thick Mooreville Formation are capable of storing some 15 million gallons. Integrity of the site has been excellent with no water-influx problems. The long-term operational history of this facility attests to the favorable physical properties of chalk as a slorage medium. 


\section{PHYSTCAL-CHEMICAL PROPERTIES}

As relatively clean carbonate rocks, chalks, chalky limestones and shaly chalks are primarily composed of the mineral calcite. As earlier noted, the calcite occurs in the form of micritic-sized particles. Strata in chalky sequences of course contain many other minerals, such as quartz, limonite, pyrite and clay minerals, the most common of which is montmorillonite (as bentonite). Interstratified marls and chalky-marly shales actually contain as much or more clay-mineral fraction than calcite.

Chalk intervals, although very fine-grained and impermeable to water, are nonetheless soft and friable in comparison to many other carbonate rocks. This is reflected in a very low compressive strength. Siegel (1967) has tabulated results for several geotechnical parameters for a variety of carbonates. Among those analyzed, chalk, selected from the Niobrara Formation, exhibited the lowest uniaxial compressive strength. Values ranged from 2000 to $3700 \mathrm{psi}$ in comparison to indurated dense limestones, which recorded values between 15,000 and 28,800 psi. Tensile strength was also among the lowest of the rocks tested. The facts that some chalk, again Niobrara, has been used as facing stone in moderate-sized buildings in Kansas, and that subsurface caverns excavated within the Mooreville Chalk of Alabama have remained stable after some initial spalling, suggest that chalky rocks may be able to perform slightly better than laboratory testing would indicate. 
The potential role of montmorillorite in chalky scquences is open to both some question and further study. As an expandablelattice clay, montmorjllonite can absorb appreciable amounts of interlayer water. Thermal energy from stored wastes vould most likely cause the expulsion of this water with attendant shrinkage of the clay. Depending upon its compositional variation, montmorillonite dehydrates in the ranges of 600 to $700^{\circ} \mathrm{C}$. Other clay minerals, depending on their chemistry and degree of crystallinity, may dehydrate at slightly lower temperatures, although some may not do so until temperatures exceed 800 to $900^{\circ} \mathrm{C}$.

Calcite, in a thermally elevated environment, decarbonizes in the range of 900 to $1000^{\circ} \mathrm{C}$. Thus, water from montmorillonite and other clays could be expected to be released before carbon dioxide is driven off the calcite. The eventual fate of potentially released $\mathrm{CO}_{2}$ is also problematical and in need of some investigation.

Montmorillonite exhibits, however, a very high ion-exchange capacity, second only to vermiculite among clay and clay-iike minerals. Whether this potentjally favorable aspect offsets the somewhat negative considexations of dehydration and shrinkage remains unanswered at this point in time.

The plasticity of chalk has not been studied as in the case of clays. Evidence of self-sealing along joints and fractures, and related adjustments in overlying beds to the compaction of the plastic micritic oozes, suggests that chalk has some degree of plasticity. What percentage has been expended through original sedimentation-lithification transformation is not known and might be very difficult to determine. It is doubtful if solidified 
chalk samples would lend themselves to the several laboratory approaches to measure plasticity in clays.

Little can be said about potential radiation effects, and, as noted above, the exact reaction to elevated thermal conditions has not yet been adequately tested.

In summary, chalks are relatively low strength, low density, very fine-grained carbonates which commonly contain montmorillonite, a clay of some potential problem in a thermal-dehydration environment. More field and laboratory investigations about the physical-chemical properties of chalky sequences are needed to provide data and answers not yet available. 
As viewed by this report, chalk-dominated sequences do show definite potential as possible sites for repository disposal of solidified radioactive wastes. This is based upon the following considerations:

1. Such sequences and/or thick sections within them arc essentially impermeable, and where very slight amounts of water may be present, there is essentially no transmissivity involved.

2. The stratigraphic units are generally widespread, reasonably thick (in excess of 500 feet) and are covered by additional thicknesses of other stratigraphic units, some of which are also impermeable.

3. Excavation within such units would be reasonable in terms of economics, especially when compared to developing equivalent space in harder, more competent rocks.

4. These sequences are located in areas of relatively low to very low seismicity.

5. There is some evidence of self-sealing or plastic behavior which might aid in reducing access via fractures and joints.

6. Some chalk-dominated sequences occur in areas of moderately mild structural deformation.

7. Regional geomorphic histories in areas containing these stratigraphic intervals suggest that downward dissection and/or lateral erosion are unlikely to breach a subsurface repository within the desired containment time of 250,000 years.

Expressed in general terms, there are, as follows, some negative aspects about chalk-bearing sequences:

1. These rosks are not totally devoid of structural elements such as joints and faults or minor zones of dissolution or chemical variation.

2. Chalks and related rock types display low compressive strength and might prove troublesome during and/or after subsurface excavation.

3. Being soft and friable, these chalky lithologies are rather. 
easily eroded if exposed to regional geomorphic processes.

4. Most sequences contain clay minerals, and particularly anounts of bentonite (montmorillonite), whose potential for swelling and shrinkage and thermally-induced dehydration coula pose problems.

5. The thermal response of such rock sequences might prove less than desirable, totally aside from the considerations about contained clay minerals.

6. As part of thicker sedimentary sections, most chalky formations have been penetrated by either petroleum or ground-water related boreholes.

7. Actively utilized ground-water aquifers may be too proximal either vertically or laterally to the repository horizon.

Framed against these opposing characteristics, is the need to assess the three principal chalky sequences described in this report. In the writer's opinion, both the Niobrara and Selma sequences would appear to have some potential. for repository use, certainly to the degree. which warrants additional, more detailed investigations and technical studies. Although neither can be cleared from having some of the negative features already outlined, the combination of a greater number of positive points tends to support the rationale for future consideration.

On the other hand, the Austin Chalk appears to suffer from several negative points. First, this unit has been subjected to a much greater level of structural disturbance. Secondly, the Austin exhibits some reasonably significant thickness changes and is the thinnest unit assessed here. Thirdly, the number of wellbore penetrations could easily prove excessive with no guarantee that all old, poorly recorded wells could be located and evaluated. Fourthly, the potential for additional structural 
deformation, despite very low seisnic risk, is more likcly to manifest where numerous regional and local structures areary exist.

In summary, the preliminary assessment is that chalk-bearing sequences show some promise and are deserving of added consideration and evaluation. Containment for hundreds of thousands of years would seem possible given certain assumptions. The most. promising units from the three studied are the Niobrara Formation and Selma Group. Regional and local conditions make the Austin more suspect: 
REFERENCES CITED

American Association of Petroleum Geologists, 1.962, Tectonic map of the United States: Washington, D. C., U. S. Geol. Survcy, 2 sheets.

American Association of Petroleum Geologists, 1967, Basement map of North America: Washington, D. C., U. S. Geol. Survey.

American Association of Petroleum Geologists, 1973, Geological highway map of Texas, Tulsa, Oklahoma.

Arkansas Geological Survey, 1929, Geologic map of Arkansas, Little Rock, Arkansas.

Arnow, T., 1963, Ground-water geology of Bexar County, Texas: U. S. Geol. Survey Water-Supply Paper 1588, 36 p.

Bollinger, G. A., 1973, Seismicity of the Southeastern United States: Bull. Seismo. Soc. Amer., v. 63, no. 5, p. 1785-1803.

Carlson, M. P., 1967, Precambrian well data in Nebraska including rock type and surface configuration: Neb. Geol. Survey Bull. $25,12.3 \mathrm{p}$.

Cobban, W. A., and Reeside, J. B., Jr., 1952, Correlation of the Cretaceous formations of the western interior of the United States: Geol. Soc. Amer. Bul1., v. 63, no. 10, p. 1011-1044.

Coffman, J. L., and von Hake, C. A., eds., 1973, Earthquake history of the United States: National Oceanic and Atmospheric Administration, 208 p.

Condra, G. E., and Reed, E. C., 1936, Water-bearing formations of Nebraska: Neb. Geol. Paper No. 10, $24 \mathrm{p}$.

Condra, G. E., and Reed, E. C., 1943, The geological section of Nebraska: Neb. Geol. Survey Bull. $14,82 \mathrm{p}$.

Condra, G. E., and Reed, E. C., 1950, Correlation of the formations of the Laramie Range, Hartville Uplift, Black Hills and western Nebraska: Neb. Geol. Survey Bull. 13-A (rev. ed.), $52 \mathrm{p}$.

Dane, C. H., Pierce, W. G., and Reeside, J. B., Ir., 1936, The stratigraphy of the Upper cretaceous rocks north of the Arkansas River in eastern Colorado: U. S. Geol. Survey Prof. Paper 186-K, p. 207-232.

Deussen, A., 1924, Geology of the coastal plain of Texas west of Brazos River: U. S. Geol. Survey Prof. Paper 126, 139 P. 
Durham, C. O., Jr., and Mutray, G. E., 1967, Toctonism of Itlantic: and Gulf Coastal Province: Amer. Jour. Sci., v. 265, p. 428441 .

Earthquake Information Bulletin, 1970a, Earthquake history of Alabarna: U. S. Geol. Survey Publ., v. 2, no. 1, p. 22-24.

Earthquake Information Bulletin, 1970b, Earthquake history of Arkansas: U. S. Geol. Survey Publ., v. 2, no. 4, p. 2l-23.

Earthquake Information Bulletin, 1970C, Earthquake history of Colorado: U. S. Geol. Survey Publ., v. 2, no. 6, p. 24-27.

Earthquake Information Bulletin, 1972, Earthquake history of Kansas: U. S. Geol. Survey Publ., v. 4, no. 6, p. 26-28.

Evans, D., 1966, The Denver area earthquakes and the Rocky Mountain Arsenal well: Mtn. Geologist, v. 3, p. 23-36.

Fenneman, N. M., 1931, Physiography of western United States: New York: McGraw-Hill, $534 \mathrm{p}$.

Freeland, G. L., and Dietz, R. S., 1971, Plate-tectonic evolution of Caribbean-Gulf of Mexico Region: Nature, v. 232, p. 20-23.

Frey, R. W., 1972, Paleoecology and depositional environment of Fort Hays Limestone Member, Niobrara Chalk (Cretaceous), west-central Kansas: Univ. Kansas Paleon. Contributions, Lawrence, Kansas, Art. $58,72 \mathrm{p}$.

Frye, J. C., and Leonard, A. R., 1949, Geology and ground-water resources of Norton County and northwestern Philiips County, Kansas: Kansas Geol. Survey Bull. $81,144 \mathrm{p}$.

Gonzales, S., 1975, Geohydrologic-engineering geology evaluation of the Selma Group in western Alabuma and northeast

Miesissippi for possible radioactive waste disposal: ORNL Consult. Rept. $99 \mathrm{p}$.

Ham, W. E., and Wilson, J. L., 1967, Paleozoic epeirogeny and orogeny in the central United States: Amer. Jour. Sci., v. 265 , p. 332-407.

Hardy, R. G., 1970, Inventory of industrial, metallic, and solidfuel minerals in Kansas: Kansas Geol. Survey Bull. 199, pt. $4,30 \mathrm{p}$.

Harvey, R. D., Frost, R. R., and Thomas, J., 1.974, Lake marls, chalks, and other carbonate rocks with high dissolution rates in $\mathrm{SO}_{2}$-scrubbing liquors: Ill. Geol. Survey Environ. Geology Note, 2 no. $68,22 \mathrm{p}$.

Hattin, D. E., and Cobban, W. A., 1965, Upper Cretaceous stratigraphy, paleontology and paleoecology of western Kansas: Geol. Soc. Amer. Ann. Meeting Field Trip Guidebook, 69 p. 
Hawkins, M. E., and Jirik, C. J., 1966, Salt domes in Texas, Iouisiana, Mississippi, Alabama, and offshore tidelarids-a survey: U. S. Bur. Mines Inf. Cir. 8313, 78 p.

Healy, J. II. , Rubey, W. W. , Griggs, D. T., and Raleigh, C. B., 1968, Jhe Denver earthquakes: Scicnce, v. 161, no. 3848, p. $130.1-1310$.

Hodson, W. G., 1963, Geology and ground-water resources of wallace County, Kansas: Kansas Geol. Survey Bull. 161., 108 p.

Hodson, W. G., 1965, Geology and ground-water resources of Trego County, Kansas: Kansas Geol. Survey Bul1. 174, 80 p.

Hodson, W. G., 1969, Geology and ground-water resources of Decatur County, Kansas: Kansas Geol. Survey Bull. 196, 41 p.

Hodson, W. G., and Wahl, K. D., 1960, Geology and ground-water resources of Gove County, Kansas: Kansas Geol. Survey Bull. $145,126 \mathrm{p}$.

Kaiser, W. R., 1974, Texas Jignite--near-surface and deep-basin resources: Bur. Econ. Geol. Rept. Inv. 79, 70 p.

Kansas Geological Survey, 1937, Geologic map of Kansas: Lawrence, Kansas.

Kansas Geological Survey, 1974, Oil and gas pipelines and industries in Kansas (map): Lawrence, Kansas.

Keroher, G. C., and others, 1966, Lexicon of geologic names of the United States for 1936-1960: U. S. Geol. Survey Bull. 1200 , Parts $1-3,4341 \mathrm{p}$.

Loetterle, G. J., 1937, The micropaleontology of the Niobrara Formation in Kansas, Nebraska, and South Dakota: Neb. Geol. Suivey Bul1. 12, $67 \mathrm{p}$.

Mellen, F. F., 1958, Cretaceous shelf sediments of Mississippi: Miss. Geol. Survey Bull. 85, 112 p.

Merriam, D. F., 1956, Subsurface correlation and stratigraphic relation of rocks of Mesozoic age: Kans. Geol. Survey Oil and Gas. Inv: 14, Plates 1, 2, and 3.

Merriam, D. F., 1963, The geologic history of Kansas: Kans. Geol. Survey Bull: $162,317 \mathrm{p}$.

Meyerhoff, A. A., 1967, Future hydrocarbon provinces of Gulf of Mexico-Caribbean region: Gulf Coast Assoc. Geol. Soc. Trans., v. 17, p. 217-260.

Mississippi Geological Survey, 1969, Geologic map of Mississippi: Jackson, Mississippi. 
Murray, G. E., 3.361; Geology of the Atlantic and Gull Coastal

Province of North Anerica: New York, Harper \& bros., 692 p.

National Oceanic and Atmospheric Administration, 1970, Seismic risk map of the United States: U. S. Dept. of Commerce.

Nebraska Geological Survey, 1950, Geologic map of Nebraska: Lincoln, Nebraska.

Newton, J. G., Sutcliffe, H., and LaMoreaux, P. E., 1961., Geology and ground-water resources of Marengo County, Alabama: Ala. Geol. Survey County Rept. 5, 443 p.

Paine, W. R., and Meyerhoft, A. A., 1970, Gulf of Mexico Basin-interactions among tectonics, sedimentation, and hydrocarbon accumulation: Trans. Gulf Coast Assoc. Geol. Soc., v. 20 , p. $5-44$.

Risser, H. E., 1960, Kansas building stone: Kans. Geol. Survey Bull. 142, pt. 2, p. 53-122.

Rouse, J. T., 1944, Correlation of the Pecan Gap, wolfe City, ana Annona Formations in East Texas: Amer. Assoc. Pet. Geol. Bull., v. 28, no. 4, p. 522-530.

Runnels, R. T., and Dubins, I. M., 1949, Chemjcal and petrographic studies of the Fort Hays Chalk in Kansas: Kans. Geol. Survey Bull. $82,36 \mathrm{p}$.

Schneider, K. J., and Platt, A. M., eds., 1974, High-level radioactive waste management alternatives: Richland, Washington, Battelle Pacific Northwest Laboratories, v. 2, sec. 4.

Schoewe, W. H., 1949, The geography of Kansas: Trans. Kansas Acad. Sci., v. 52, no. 3, p. $261-333$.

Schumn, S. A., 1963, Tle aisparity between present rates of denundation and orogeny: U. S. Geol. Survey Prof. Paper $454-\mathrm{H}, \mathrm{P}$. $\mathrm{HI}-\mathrm{HI} 3$.

Scott, G. R., and Cobban, W. A., 1964, Stratigraphy of the Niobrara Formation at Pueblo, Colorado: U. S. Geol. Survey Prof. Paper $454-\mathrm{L}, 30 \mathrm{p}$.

Sellards, E. H., 1936; Structural map of Texas: Texas Bur. Econ. Geol., Austin, Texas.

Siegel, F. R., 1967, Properties and uses of the carbonates; in Carbonate rocks--physical and chomical aspects, G. V. Chilingar, H. J. Bissell and R. W. Fairbridge, eds., : Amsterdam, Elsevier Publ. Co., p. 343-393. 
Stephenson, I. W., 1.918, A coitribution to the geology of northeastern Texas and southern Oklahoma: U. S. Geol. Survey' Prof. Paper 120, p. 129-163.

Stephenson, L. W., 1936, Stratigraphic relations of the Austin, Taylor, and equivalent formations in Texas: U. S. Geol. Survey Prof. Paper 186-G, P. 133-146.

Stephenson, L. W., King, P. B., Monroe, W. H., and Imlay, R. W., 1942, Correlation of the outcropping Cretaceous formations of the Atlantic and Gulf Coastal Plain and Trans-Pecos Texas: Geol. Soc. Amer., v. 53, p. 435-448.

Stewart, G. F., and Dort, W., Jr., 1973, Statistical prediction of probable depth of erosion in central Kansas during the next one million years (abs.): Geol. Soc. Amer. Abs., v. 5 , no. 3, p. 281 .

Sundstrom, R. W., Hastings, W. W., and Broadhurst, W. L., 1948, Public water supplies in eastern Texas: U. S. Geol. Survey water Supply Paper 1047, $285 \mathrm{p}$.

Texas Bureau of Economic Geology, 1967, Geologic atlas of Texas-Palestine sheet: Austin, rexas.

Texas Bureau of Economic Geology, 1970, Geologic atlas of Texas-Waco sheet: Austin, Texas.

Texas Bureau of Economic Geology, 1972, Geologic atlas of Texas-Dallas sheet: Austin, Texas.

Texas Bureau of Economic Geology, 1974a,. Geologic atlas of Texas-Austin sheet: Austin, Texas.

Texas Bureau of Economic Geology, 1974b, Geologic atjas of Texas-San Antonio sheet: Austin, Texas.

Texas Bureau of Economic Geology, 1974C, Geologic atlas of Texas-Seguin sheet: Austin, Texas.

Thornbury, W. D., 1965, Regional geomorphology of the United States: New York, John Wiley \& sons, $609 \mathrm{p}$.

U. S. Geological Survey, 1935, Geologic map of Colorado: Denver, colorado.

U. S. Geological Survey, 1964, Physical divisions of the United States (map after Fenneman): Washington, D. C.

Weeks, W. B., 1938, South Arkansas stratigraphy with emphasis on the older coastal plain beds: Amer. Assoc. Pet. Geol. Bull., v. 22 , no. 8 , p. 953-983.

Weeks, A. W., 1945, Balcones, Luling, and Mexia fault zones in Texas: Amer. Assoc. Pet. Geol. Bull., v. 29, no. 12, p. 1733-1737. 